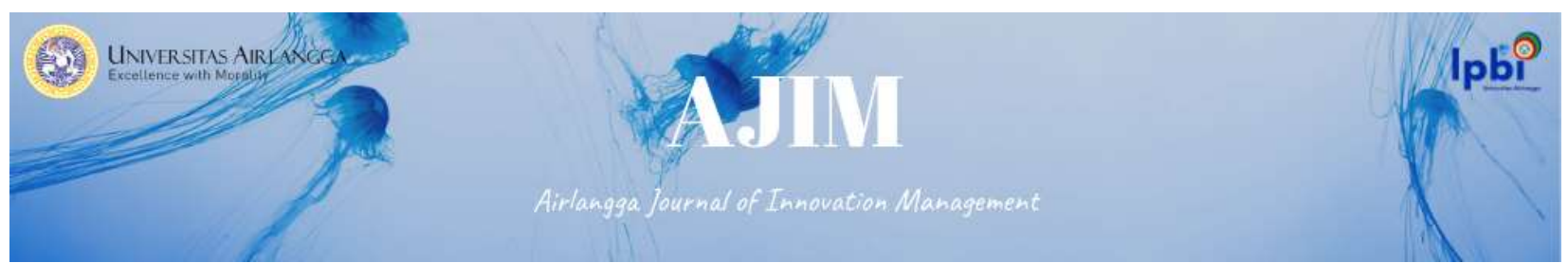

Vol.1 No.1, June 2020

ISSN: 2722-5062

DOI : 10.20473/ajim.v1i1.19413

\title{
THE INNOVATION MODEL OF TURBINE ENGINE COMPRESSOR TO SIMULATE THE PERFORMANCE IN OIL AND GAS INDUSTRY
}

\author{
Damianus Mario Ricky Fernando', Joko Waluyo ${ }^{2}$, \\ 'Magister Teknik Sistem \\ Universitas Gadjah Mada, Yogyakarta, Indonesia \\ ${ }^{2}$ Departement of Mechanical Engineering \\ Universitas Gadjah Mada, Yogyakarta, Indonesia \\ *E-mail: damianus.mario.r@mail.ugm.ac.id
}

\begin{abstract}
In 1997s, East Kalimantan had several oil and gas fields that had reservoir pressure in the High-Pressure category. However, a few years later, the pressure continued to decrease until it reached Low Pressure, so the compressor is needed to produce high-pressure. In this study, an explanation of the process of making a turbine engine performance simulation model in 2019 is discussed and predicting turbine engine performance in the following years. This is important because the compressor is a vital tool in the oil and gas industry. Furthermore, it works continuously so that performance must be considered. In general, the simulation model equation consists of several parameters that exist in the Brayton cycle in the gas turbine in steady conditions. Simultaneous equation solving in simulation models using the Newton-Raphson method. The simulation results show that the performance of the Turbine Engine Compressor in 2019 has a net power of $20.58 \mathrm{MW}$ with a cycle efficiency of $23.06 \%$. This can be developed for plans for maintenance applications to improve efficiency changes.
\end{abstract}

Keywords: simulation, Newton -Raphson, gas turbine, pressure, compressor

\begin{abstract}
ABSTRAK
Pada tahun 1997, Kalimantan Timur memiliki beberapa ladang minyak dan gas yang memiliki tekanan reservoir dalam kategori tekanan tinggi. namun beberapa tahun kemudian, tekanan terus menurun hingga mencapai tekanan rendah, sehingga kompresor diperlukan untuk menghasilkan tekanan tinggi. Dalam penelitian ini, dibahas tentang proses pembuatan model simulasi kinerja mesin turbin pada tahun 2019 dan memprediksi performa mesin turbin di tahun-tahun berikutnya. Hal ini penting karena kompresor adalah alat vital dalam industri minyak dan gas. dan itu bekerja terus menerus sehingga kinerja harus diperhatikan. Secara umum, persamaan model simulasi terdiri dari beberapa parameter yang ada dalam siklus brayton di turbin gas dalam kondisi stabil. Penyelesaian persamaan simultan dalam model simulasi menggunakan metode newton-raphson. Hasil simulasi menunjukkan bahwa kinerja kompresor mesin turbin pada 2019 memiliki daya bersih 20,58 mw dengan efisiensi siklus 23,06\%. Penelitian ini dapat dikembangkan untuk rencana aplikasi pemeliharaan untuk meningkatkan perubahan efisiensi.
\end{abstract}

Kata kunci: simulasi, Newton-Raphson, turbin gas, tekanan, kompresor

\section{INTRODUCTION}

The use of compressors in the oil and gas industry is now very important, especially for supporting changes in pressure from the reservoir, which slowly decreases(Kalimattulah, 2019). In the large-scale oil and gas industry using gas turbine as the prime mover of the compressor is called the Turbine Engine Compressor. The changing of pressure in the oil and gas industry system is caused by 


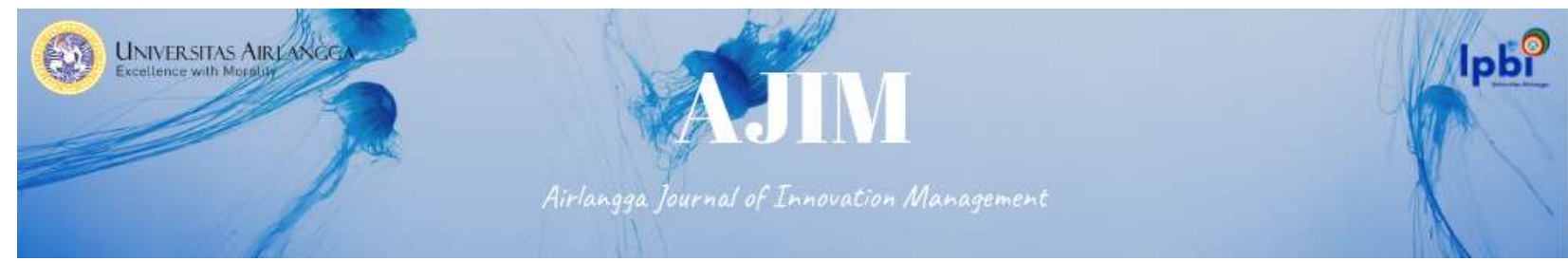

several things such as a decrease in pressure that occurs in the reservoir which can result in decreased gas deliverability so the pressure must be maintained by installing a compressor on the installation(INDONESIE, 2007).In addition to the delivery of gas using a very long pipeline then the possibility of a pressure drop or pressure drop caused by the existence of friction resistance to changes in the cross-section angle of the pipe through which the gas caused a large pressure loss (Mahmudin, 2018).In this case study the delivery of gas through a pipeline along $65.97 \mathrm{~km}$ so that the installation of a Turbine Engine Compressor is needed to help deliver gas to consumers(Total Finaelf, 2001).

Pressure decrease also happened in upstream, especially in a gas well. Based on production, reservoir pressure will gradually decrease. Since 2003, this area operates in Medium Pressure mode (MP) and

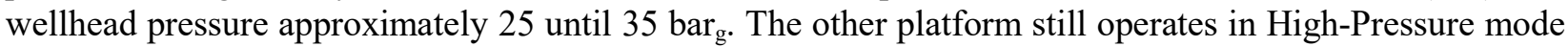
(HP) because it has wellhead pressure approximately 100 until 150 barg. However, in 2008 wellhead pressure gradually decreases until reach Low-Pressure mode (LP). Oil and gas industry has to install a turbine engine compressor to maintain gas deliverability of this area. Turbin engine compressor has been installed in parallel mode when normal condition both of them running together but when one of them perform scheduled maintenance or got some problem so only one of turbine engine compressor will be running. If only one turbine engine compressor running, it makes the turbine engine compressor running harder than normal condition, and if an unexpected shutdown happened there is no more turbine engine compressor standby. This condition makes the loss of production, and it is very bad (INDONESIE, 2007). That condition make a turbine engine compressor is one of the main concern in the oil and gas industry, so the condition of the turbine engine compressor have to be monitored carefully.

The role of the simulation model in predicting the performance of the Turbine Engine Compressor throughout the year is very important to evaluate the performance of the turbine. By evaluating the performance of the turbine each year, it can be further developed to optimize the maintenance of the turbine. In 2017 the turbine performance was at $17.52 \mathrm{MW}$ with a cycle efficiency of $22.49 \%$ then the engine replacement was carried out so that the turbine performance changed to $19.86 \mathrm{MW}$ with a cycle efficiency of $30.88 \%$ (Geasang, 2017).

Based on Stoecker's research, it gives an example of a non-regenerative gas turbine cycle operating at constant speed $7200 \mathrm{rpm}(120 \mathrm{r} / \mathrm{s})$ and constant energy that was added at combustion chamber (Stoecker, 2018). This research develops a new simulation model to analyze the performance of the Turbine Engine Compressor that has variable speed and load depend on gas production in the oil and gas industry throughout the year. The advantage of this simulation is that we can see the output power produced by gas turbines throughout the year with various variations in load and energy added by regulating the fuel. From the solution side, using a simulation model with Newton-Raphson can solve iterations faster when compared to using the successive substitution method (Stoecker, 2018).

\section{LITERATURE REVIEW}

The literature review in this research is based on Stoecker's research on the design of the thermal system. His study made a simulation of the extensive thermal system such as non-regenerative gas turbine cycle. His study introduces that system simulation can also be one step in an optimization process. For example, the effect on the output of the system, if we make a small change in the system such as the size of the combustion chamber, it will give an effect to the output (Stoecker, 2018). Stoecker's objective research to determine the power output at the shaft, if the gas turbine was added $8000 \mathrm{KW}$ of energy by burning fuel and has constant operating speed at $7200 \mathrm{rpm}(120 \mathrm{r} / \mathrm{s})$. Figure 1 shows us about the simulation of axial flow compressor operating at $120 \mathrm{r} / \mathrm{s}$ and $101 \mathrm{KPa}$ inlet pressure. Stoecker simulation based on constant speed and constant fuel rate. Based on the basic principle of stocker's research, this study will simulate the real operating parameter of the turbine engine compressor with varies load throughout 2019. 

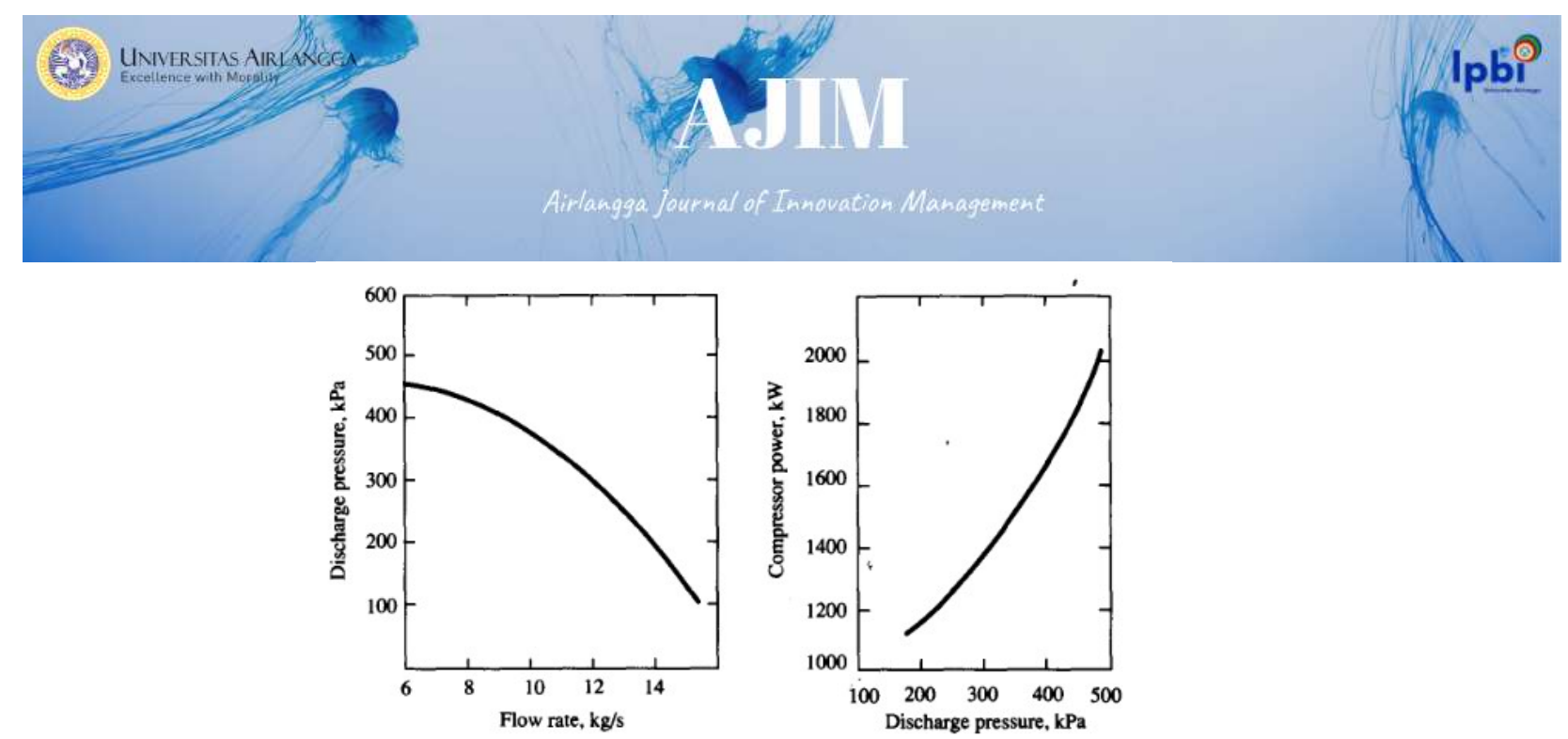

Figure 1 Performance of axial - flow compressor operating at $120 \mathrm{r} / \mathrm{s}$ with $101 \mathrm{KPa}$ inlet pressure Source: (Stoecker, 2018).

Ramadhan's research generator gas turbine in Petrokimia Gresik before and after overhaul combustion inspection. Generator gas turbine has load $19 \mathrm{MW}$, and before performed overhaul combustion inspection, its cycle efficiency is $29.3 \%$. Gas turbine performance increase after overhaul combustion inspection and reach $30.6 \%$. Based on Ramadan's research, the result of overhaul combustion inspection gives a positive effect to generator gas turbine's performance. Ramadhan's method in this research uses the basic calculation of the Brayton cycle in generator gas turbine. His calculation divide by several stages. The first stage consists of calculation in inlet guide van to find fluid enthalpy. Then second stage calculation in the compressor to calculate the parameter in the compressor. The third stage consists of a calculation in the combustion chamber that combustion happened. The fourth stage consists of expansion in power turbine until exhaust. The last stage is to calculate the performance of the generator gas turbine part by part (Ramadhan, 2018). Ramadhan's method in calculating generator gas turbine only in instantaneous time. So this study will make a simulation to calculate the performance of the turbine engine compressor the whole year in 2019.

Oil and gas industry is one of the major industry in Indonesia, one of them in East Kalimantan. This processing area main product is gas, and its delivery to Bontang, which has distance $65.97 \mathrm{~km}$ (TOTAL, 2002). Based on Mahmuddin's research, the pressure drop will be happened due to the length of the pipe, and the pressure drop will be greater if there are pipe bends during the trip of fluida. Not only pipe bends but also rate of fluida can affect the decrease of pressure. Figure 2 shows us Mahmuddin's research that a higher degree of pipe bend can give higher decrease of pressure and higher rate of fluida can also give a higher decrease in pressure. SD 20 mean 20 degree of pipe bend and its reduce pressure until $98 \mathrm{~Pa}$ with flow rate $0.0003 \mathrm{~m}^{3} / \mathrm{s}$ and SD 160 mean 160 degrees of pipe bend and its reduce pressure until $431 \mathrm{~Pa}$ with same flow rate. So we need a Turbine Engine Compressor to increase the pressure so we can deliver gas from one place to another place (Mahmudin, 2018). The distance of gas delivery is 65.97 $\mathrm{km}$, so its need to increase the pressure approximately 50 bar to deliver the product. Upstream pressure of the system is 17 bar $_{\mathrm{g}}$ then turbine engine compressor will increase the pressure until reach 50 bar $_{\mathrm{g}}$ then the product will be delivered. That is the main reason for the oil and gas industry have to maintain the performance of the turbine engine compressor to keep the continuity of the process. This study will simulate the performance of a turbine engine compressor to know the thermal efficiency, and for further research, it can be used to optimize the turbine engine compressor and maintenance schedule. 

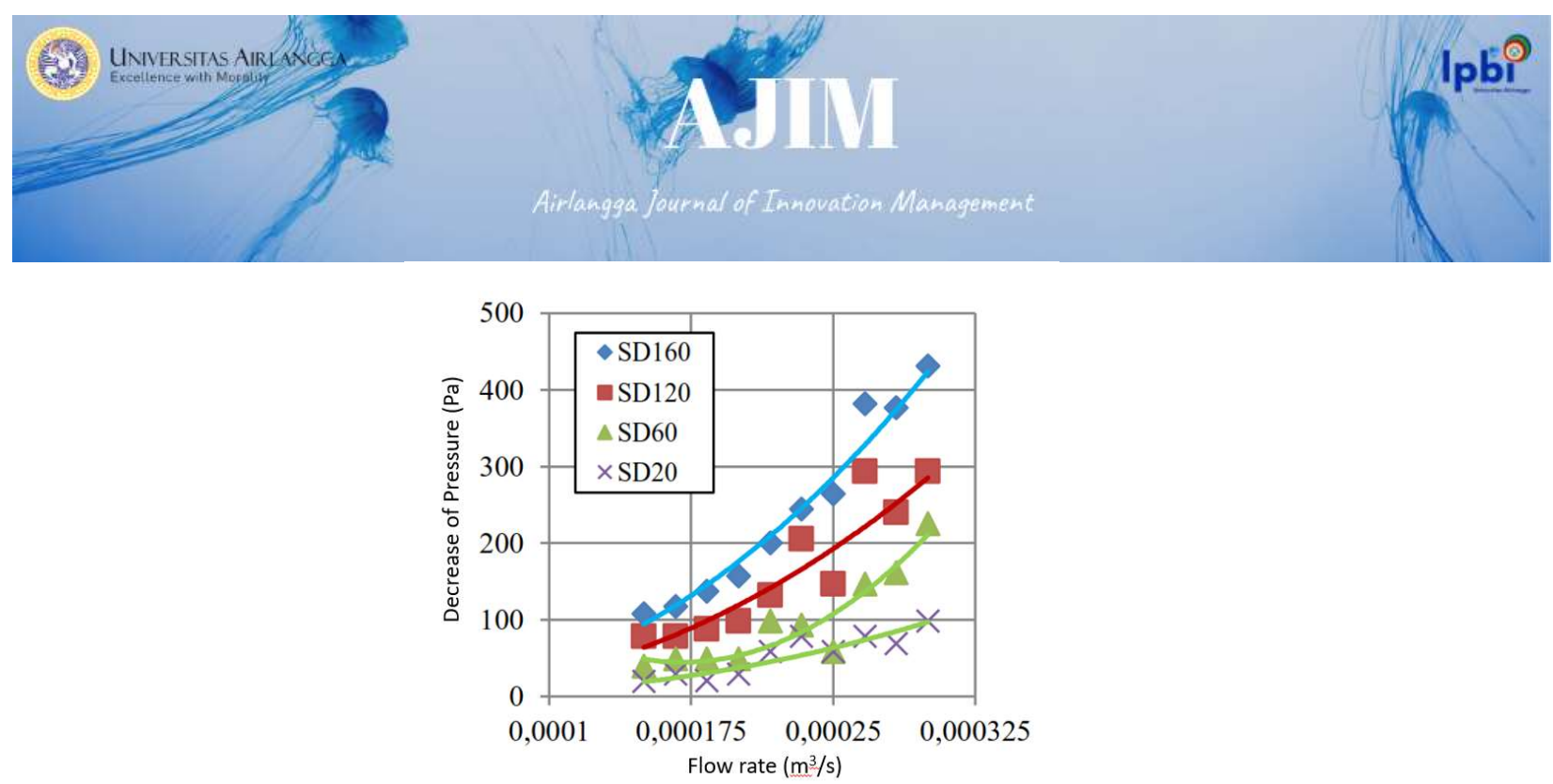

Figure 2 Pressure drop curve with variations in turn angle Source: (Mahmudin, 2018)

According to operational on-site, the gas generator has reached 24.012 hours, at which the unit will undergo a major overhaul to restore its performance and maintain its reliability. Therefore, in order to maintain the integrity of the turbo compressor package, it is decided to replace GG with a spare unit. Based on Gaesang's report, when he performed engine replacement of turbine engine compressor, we can see the difference in thermal efficiency before and after the engine replacement (Geasang, 2017). In 2017, the turbine engine compressor had engine replacement because the performance gradually decreases and cycle efficiency reaches $22.49 \%$, and then they perform engine replacement to increase the efficiency of the turbine engine compressor. In normal condition, two turbine engine compressors will be running in parallel mode. If one of them was performed maintenance, so only one turbine engine compressor running and reduce the capacity of gas delivery. After the engine replacement was performed, the cycle efficiency increase and reach $30.88 \%$. That is the reason for the turbine engine compressor have to monitor the reliability of turbine engine compressor. This study will help the oil and gas industry to simulate the performance of the turbine engine compressor if any changing of the parameter happened or to optimize the performance of the turbine engine compressor.

\section{METHODS}

The main objective of this research is to create a performance simulation model of the Turbine Engine Compressor which will be used to evaluate the performance of each year. In general, this research methodology covers the following matters:

1. Data collection parameters of the gas turbine reading each day.

2. Make an equation model for the axial flow compressor and gas turbine.

3. Determine the basic equations in the simulation model

4. Determine the initial value that will be used.

5. Completion of the basic equations in the simulation model by using iterations based on the Newton-Raphson method to obtain convergent results.

6. Analyze the cycle efficiency of the Turbine Engine Compressor.

\section{Data Parameter of Turbine Engine Compressor.}

The parameter data used is obtained from direct reading in the field every day, which is then processed to create a simulation model. There are several simplifications made in this analysis, which are as follows(Stoecker, 2018):

1. It is assumed that the gas entering the system is perfect gas with a constant heat capacity at $C_{P}=$ $1,005 \mathrm{KJ} /(\mathrm{Kg} . \mathrm{K})$

2. Ignores the increase in the mass of the fuel in the combustion chamber so that the mass flow rate $\dot{m}$ that enters the system is constant.

3. The pressure drop that occurs in the combustion chamber of $0.2 \%$

4. Ignore the existence of heat transfer to the environment. 


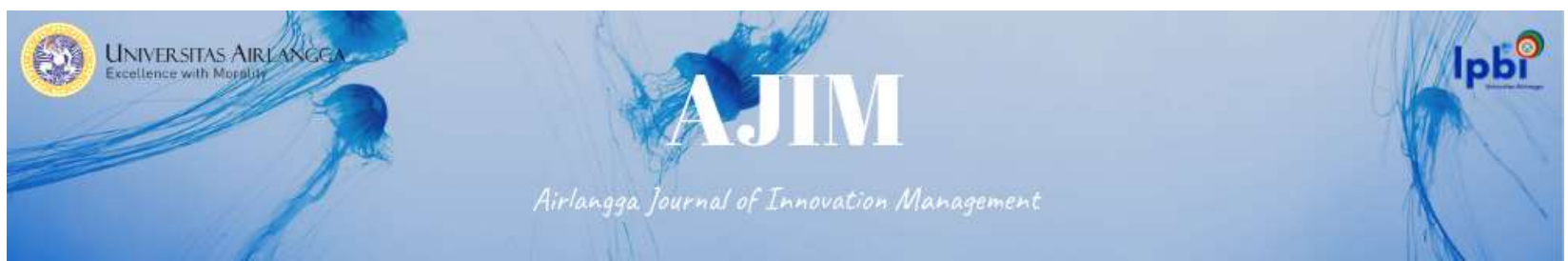

Based on this simplification, an analysis is carried out based on the parameters obtained, as shown in Figure 3 below. Figure 3 is a display shown by the Human to Machine Interface Panel (HMI Panel) with RS Logic R 5.0 type to record Turbine Engine Compressor parameter data in the field (Electric, 2001).

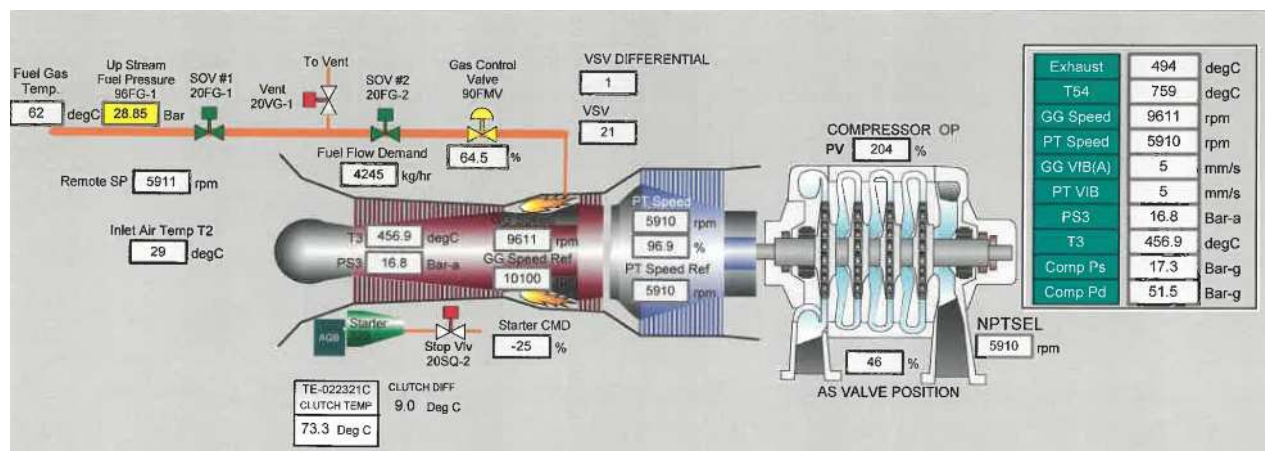

Figure 3 Display Parameter Turbine Engine Compressor

Source: (Electric, 2001)

\section{Basic Equation.}

The basic equation is developed from the parameter data contained in the Brayton cycle of the Turbine Engine Compressor. The basic equation is taken from two main parts. In Figures 4 and 5 the data comes from the axial flow compressor, and in Figures 6 and 7 come from the gas turbine.

Figure 4 shows the pressure data coming out of the axial flow compressor $\left(\mathrm{P}_{2}\right)$ against the mass flow rate of the incoming air $(\dot{m})$ while in Figure 5 shows the energy data required by the axial flow compressor $\left(\mathrm{W}_{\mathrm{C}}\right)$ for the amount of pressure coming out of the axial flow compressor $\left(\mathrm{P}_{2}\right)$. In Figure 6 is the data obtained in the turbine by comparing the mass flow rate $(\dot{\mathrm{m}})$ with the inlet pressure on the turbine $\left(\mathrm{P}_{3}\right)$ and in Figure 7 is a graph of the power generated by the turbine $\left(\mathrm{W}_{\mathrm{T}}\right)$ against the inlet pressure on the turbine $\left(\mathrm{P}_{3}\right)$. These data were analyzed from reading parameters in the field throughout 2019.

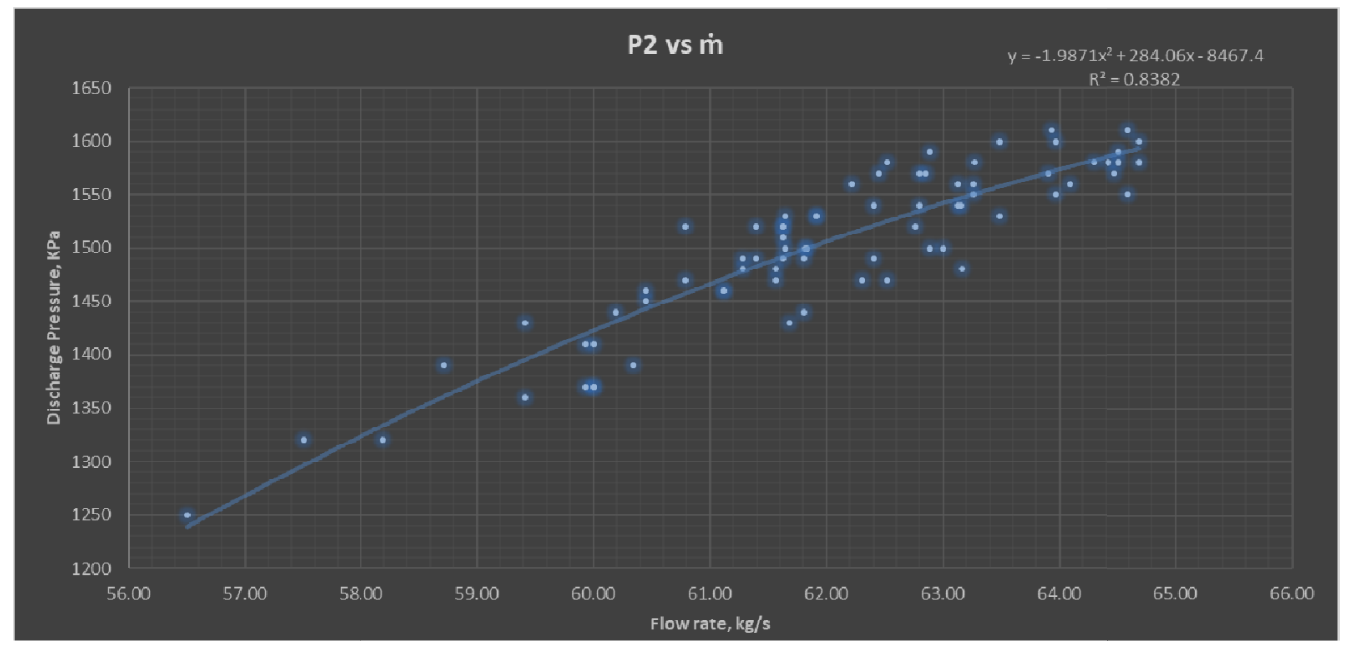

Figure 4Outlet pressure $\left(\mathrm{P}_{2}\right)$ on the mass flow rate $(\dot{\mathrm{m}})$ Source: simulated by authors 


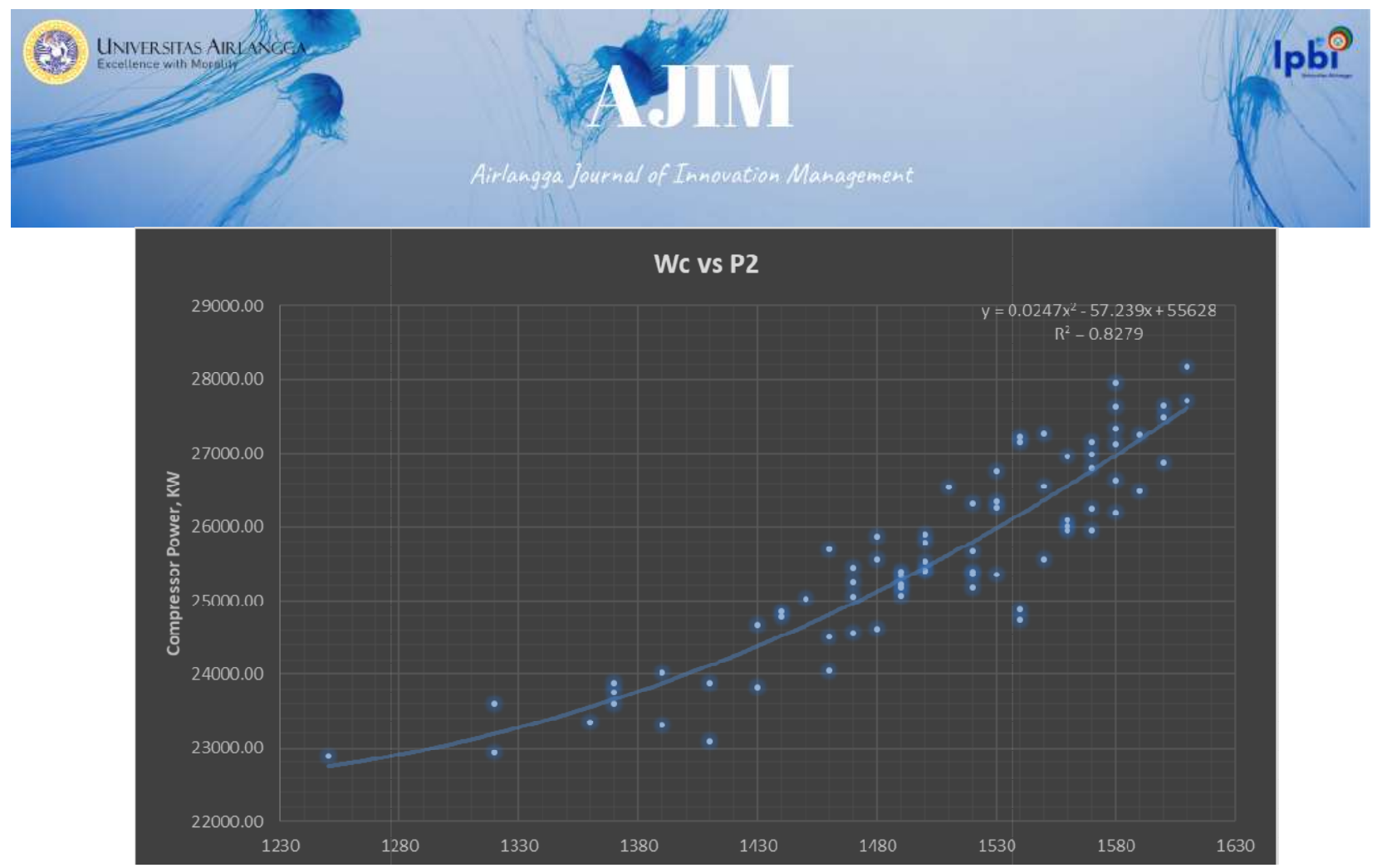

Figure 5Axial flow compressor power $\left(W_{C}\right)$ to outlet pressure $\left(P_{2}\right)$ Source: simulated by authors

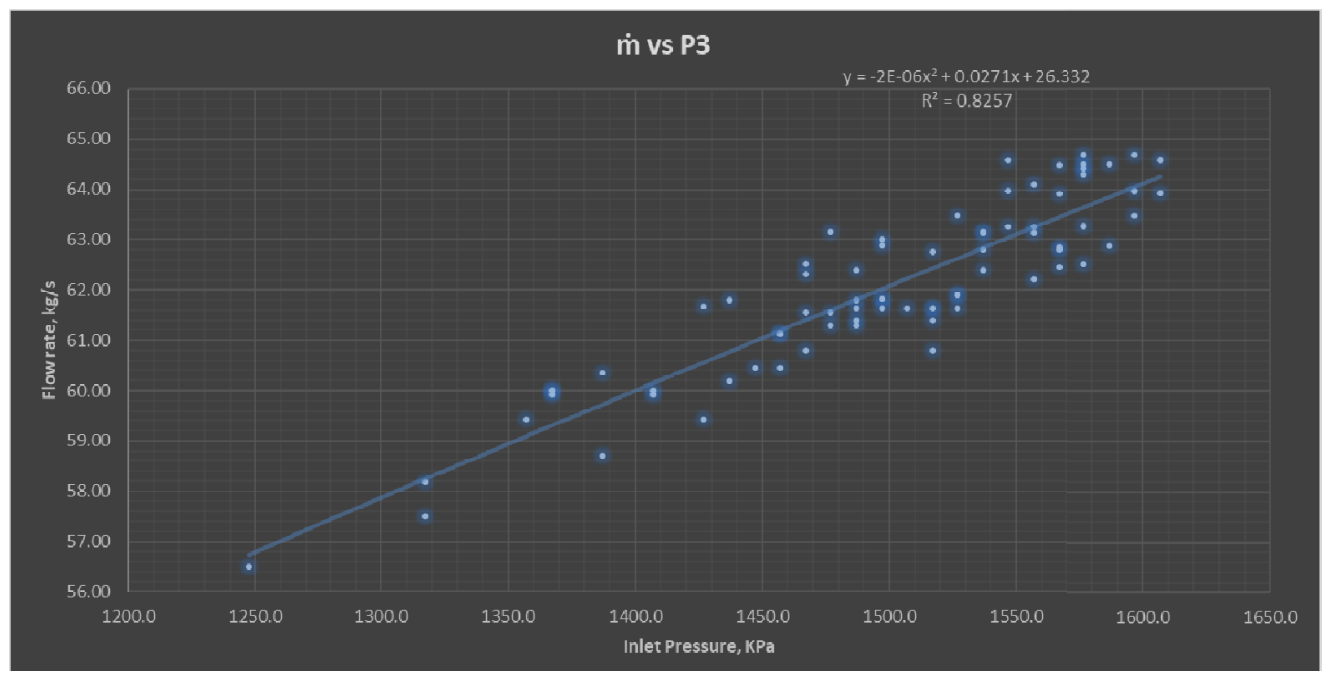

Figure 6. Mass flow rate (im) to turbine inlet pressure $\left(\mathbf{P}_{3}\right)$

Source: simulated by authors 


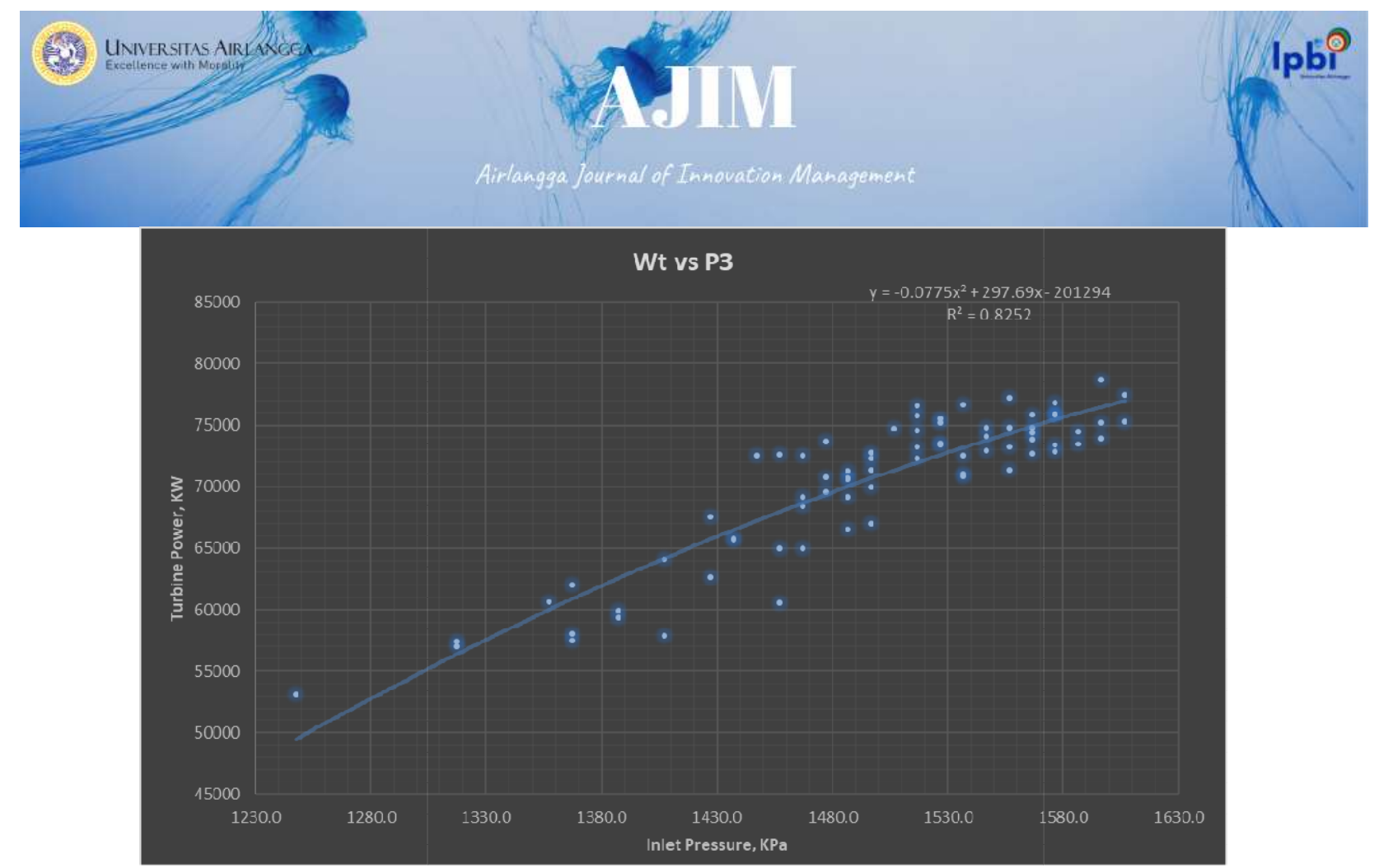

Figure 7. Turbine power $\left(\mathrm{W}_{\mathrm{T}}\right)$ to turbine inlet pressure $\left(\mathbf{P}_{3}\right)$ Source: simulated by authors

Based on the data obtained from the field shown in Figure 4 through Figure 7, the equation fitting method obtained four basic equations that will be used with the Newton-Raphson simulation method.

The equation obtained from the curves shown in Figures 2 through 5 is as follows:

$$
\begin{aligned}
& P_{2}=-1.9871 \dot{\mathrm{m}}^{2}+284.06 \dot{\mathrm{m}}-8467.4 \\
& W_{C}=0.0247 P_{2}^{2}-57.239 P_{2}+55628 \\
& \dot{\mathrm{m}}=-2 \times 10^{-6} P_{3}^{2}+0.0271 P_{3}+26.332 \\
& W_{T}=-0.0775 P_{3}^{2}+297.69 P_{3}-201294
\end{aligned}
$$

From these four equations we add one more equation to find the Wnett value to find out the net power generated by the Brayton cycle in the Turbine Engine Compressor.

$$
W_{\text {nett }}=W_{T}-W_{C}
$$

Based on these equations, several unknown variables are obtained that will be used in the simulation (Stoecker, 2018). The unknown variable that we have to determine are $\mathrm{P}_{2}, \dot{\mathrm{m}}, \mathrm{P}_{3}, \mathrm{~W}_{\mathrm{C}}, \mathrm{W}_{\mathrm{T}}$ and $\mathrm{W}_{\text {nett }}$

\section{Newton - Raphson Method.}

After the basic equations are obtained, the next step is to solve the simulation model using The Newton-Raphson method. The advantage of using this method is that it can solve equations that have convergent values with faster iterations, by choosing an initial value that is close to (Chapra \& Canale, 2006)

The fifth writing in the form of a matrix equation can be written as follows:

$$
\left[\begin{array}{cc}
P 2+1.9871 \dot{\mathrm{m}} 2-284.06 \dot{\mathrm{m}}+8467.4 & =0 \\
W c-0.0247 P 22+57.239 P 2-55628 & =0 \\
\dot{\mathrm{m}}+2 x 10-6 P 32-0.0271 P 3-26.332 & =0 \\
W t+0.0775 P 32-297.96 P 3+201294 & =0 \\
\text { Wnet }-W t+W c & =0
\end{array}\right]
$$

Based on the matrix shown in equation (6), iterations are performed using the Newton-Raphson method for multiple equations and unknowns. The value of equation (6) is iteratively searched until the maximum percentage of errors possessed reaches the desired value. 


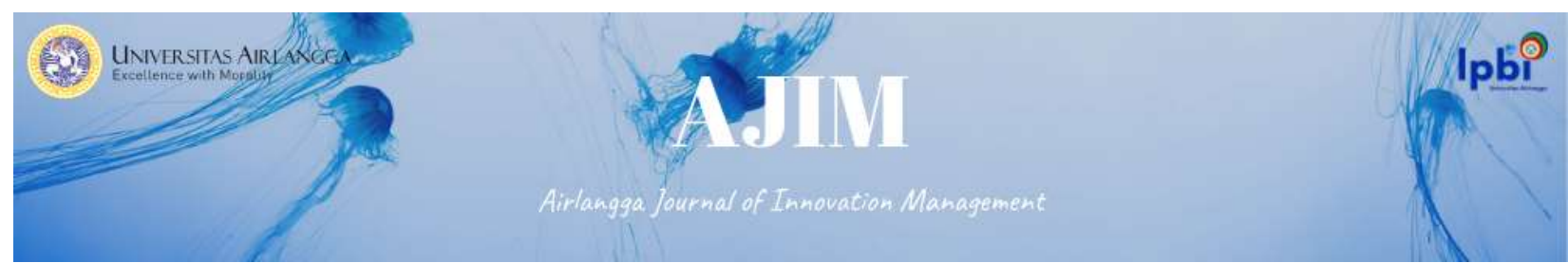

\section{RESULTS AND DISCUSSION}

This simulation model is implemented in the Turbine Engine Compressor, which works to increase the gas pressure from $14 \mathrm{bar}_{\mathrm{g}}$ to $50 \mathrm{bar}_{\mathrm{g}}$ in 2019. In Table 1 we can see several fixed parameters used in the analysis of model calculations.

Table 1. Turbine Parameter.

\begin{tabular}{lc}
\hline \multicolumn{1}{c}{ Variable } & Value \\
\hline Air Heat Capacity (Cp) & $1.005 \mathrm{KJ} / \mathrm{Kg} . \mathrm{K}$ \\
Lower Heating Value (LHV) fuel gas & $47324.6 \mathrm{KJ} / \mathrm{Kg}$ \\
& $0.2 \%$ \\
Pressure drop in Combustion Chamber & \\
\hline
\end{tabular}

\section{Source: Processed by authors}

The newton-Raphson method uses an initial value of outlet pressure axial flow compressor $\left(\mathrm{P}_{2}\right) 1200$ $\mathrm{KPa}$, air mass flow rate $(\dot{\mathrm{m}}) 55 \mathrm{Kg} / \mathrm{s}$, the power used compressor $\left(\mathrm{W}_{\mathrm{C}}\right) 22.5 \mathrm{MW}$, turbine gas inlet pressure $\left(\mathrm{P}_{3}\right) 1100 \mathrm{KPa}$, the power produced by the turbine gas $\left(\mathrm{W}_{\mathrm{T}}\right)$ is $43 \mathrm{MW}$, and the net power $\left(\mathrm{W}_{\text {nett }}\right)$ is $20 \mathrm{MW}$. Based on the initial value, iterations are performed as shown in Table 2 and Table 3 as follows

Table 2. Axial flow compressor parameter values in the simulation.

\begin{tabular}{cccc}
\hline Iteration & $\mathrm{P}_{2}(\mathrm{KPa})$ & $\dot{\mathrm{m}}(\mathrm{Kg} / \mathrm{s})$ & $\mathrm{W}_{\mathrm{C}}(\mathrm{KW})$ \\
\hline 0 & 1200 & 55 & 22500 \\
1 & 1186.96 & 55.642 & 24030.254 \\
2 & 1191.196 & 55.722 & 21994.284 \\
3 & 1191.234 & 55.723 & 22488.708 \\
4 & 1191.234 & 55.723 & 22493.207 \\
5 & 1191.234 & 55.723 & 22493.207 \\
6 & 1191.234 & 55.723 & 22493.207 \\
7 & 1191.234 & 55.723 & 22493.207 \\
8 & 1191.234 & 55.723 & 22493.207 \\
9 & 1191.234 & 55.723 & 22493.207 \\
\hline
\end{tabular}

\section{Source: Processed by authors}




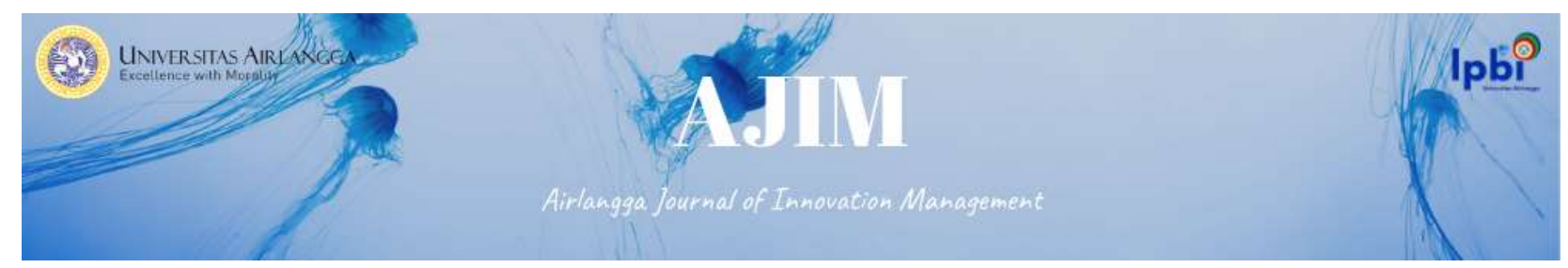

Table 3. The value of the turbine gas parameter in the simulation.

\begin{tabular}{cccc}
\hline Iteration & $\mathrm{P}_{3}(\mathrm{KPa})$ & $\mathrm{W}_{\mathrm{T}}(\mathrm{KW})$ & $\mathrm{W}_{\text {nett }}(\mathrm{KW})$ \\
\hline 0 & 1100 & 43000 & 20000 \\
1 & 1184.572 & 43169.545 & 19139.291 \\
2 & 1188.814 & 43077.435 & 21083.150 \\
3 & 1188.852 & 43079.233 & 20590.525 \\
4 & 1188.852 & 43079.233 & 20586.016 \\
5 & 1188.852 & 43079.233 & 20586.016 \\
6 & 1188.852 & 43079.233 & 20586.016 \\
7 & 1188.852 & 43079.233 & 20586.016 \\
8 & 1188.852 & 43079.233 & 20586.016 \\
9 & 1188.852 & 43079.233 & 20586.016 \\
\hline
\end{tabular}

\section{Source: Processed by authors}

Figure 8 shows the $\mathrm{W}_{\text {nett }}$ values obtained from iterations by the Newton-Raphson method. From Figure 8 , it can be seen that the iteration reaches convergence at around four times iteration. Based on Table 2 and Table 3 , the value of $\mathrm{W}_{\mathrm{T}}$ and $\mathrm{W}_{\mathrm{C}}$ reaches convergence first, then the value of $\mathrm{W}_{\text {nett }}$ reaches convergence. In order to obtain a $\mathrm{W}_{\text {nett }}$ value of $20,586 \mathrm{MW}$.

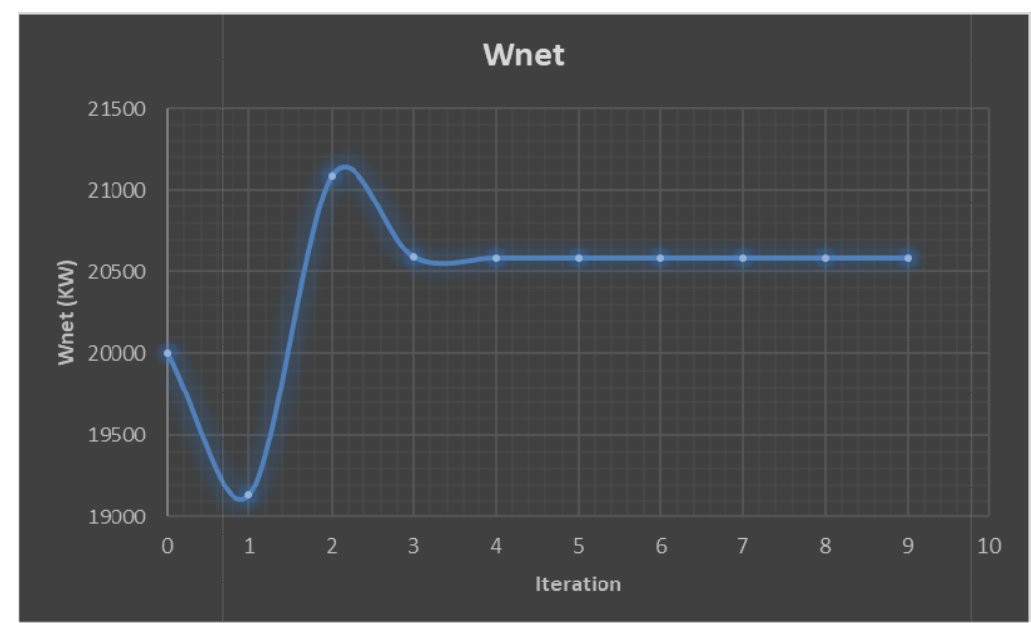

Figure $8 . \mathrm{W}_{\text {nett }}$ value convergence

Source: simulated by authors

In the field conditions, the Turbine Engine Compressor works with an average fuel gas rate of around $1.89 \mathrm{~kg} / \mathrm{s}$ so that based on the Lower Heating Value (LMV) the $\mathrm{Q}_{\text {in }}$ results are 89.443 MW which is used in the combustion chamber. So that calculated cycle efficiency in 2019 of $23.06 \%$ 


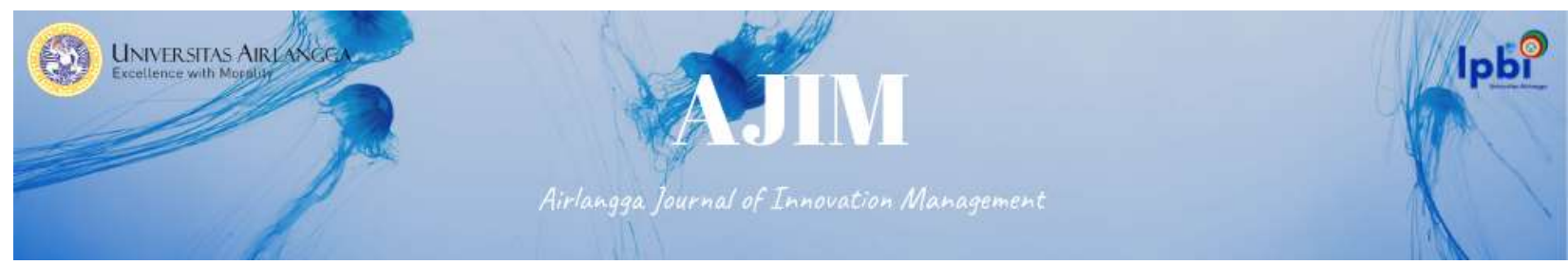

\section{CONCLUSION}

This research has developed a simulation model that can be used to predict the performance of the Turbine Engine Compressor in 2019. Based on this research, the turbine engine compressor cycle efficiency is $23.06 \%$ in the whole year. The model can accommodate the dynamics of changing parameters of the turbine cycle throughout the year because the performance of the turbine engine compressor always changes day to day depending on the change of load and condition. By using the Newton-Raphson method, it can solve iterations quickly. In this study, the fourth iteration has gotten convergent values. The results of this simulation can be used for turbine maintenance schedule because turbines are vital equipment in the oil and gas industry so that performance is a major concern. This study can help to determine the right time of scheduling maintenance depends on the performance of the turbine engine compressor for further research. The limitation of this study only analyze the performance throughout the year, and for further research, it can be used for optimization model by changing the parameter of turbine such as change the size of axial flow compressor so it will show the change of cycle efficiency too.

\section{Nomenclature}

$\begin{array}{ll}\mathrm{C}_{\mathrm{P}} & \text { Air heat capacity, } \mathrm{KJ} / \mathrm{Kg} . \mathrm{K} \\ \mathrm{HMI} & \text { Human to Machine Interface } \\ \mathrm{LHV} & \text { Lower Heating Value, } \mathrm{KJ} / \mathrm{Kg} \\ \dot{\mathrm{m}} & \text { Air mass flow rate, } \mathrm{kg} / \mathrm{s} \\ \mathrm{P}_{1} & \text { Axial flow compressor inlet pressure, } \mathrm{KPa} \\ \mathrm{P}_{2} & \text { Axial flow compressor outlet pressure, } \mathrm{KPa} \\ \mathrm{P}_{3} & \text { Turbine gas inlet pressure, } \mathrm{KPa} \\ \mathrm{P}_{4} & \text { Turbine gas outlet pressure, } \mathrm{KPa} \\ \mathrm{Q}_{\text {in }} & \text { Heat energy added to the combustion chamber, } \mathrm{MW} \\ \mathrm{T}_{1} & \text { The air temperature at the inlet axial flow compressor, } \mathrm{K} \\ \mathrm{T}_{2} & \text { The air temperature at the axial flow compressor outlet, } \mathrm{K} \\ \mathrm{T}_{3} & \text { The temperature of the air at the combustion chamber outlet, } \mathrm{K} \\ \mathrm{T}_{4} & \text { Air temperature at the exhaust, } \mathrm{K} \\ \mathrm{W}_{\mathrm{C}} & \text { The energy used in the axial flow compressor, } \mathrm{KW} \\ \mathrm{W}_{\text {nett }} & \text { Nett energy generated by the Brayton cycle, } \mathrm{KW} \\ \mathrm{W}_{\mathrm{T}} & \text { Energy produced by the gas turbine, } \mathrm{KW}\end{array}$

\section{REFERENCES}

Boyce, M. P. (2002). Gas Turbine Engineering Handbook Second Edition. Houston: Gulf Publishing Company.

Boyce, M. P. (2012). Gas Turbine Engineering Handbook fourth Edition. Oxford: Elsevier.

Chacartegui, R., Sanchez, D., Munoz, A., \& Sanchez, T. (2011). Real time simulation of medium size gas turbine. Energy Convention and Management, 713-724.

Chapra, S. C., \& Canale, R. P. (2010). Numerical Method for Engineers sixth edition. New York: McGraw-Hill.

Ciggaar, J. (2010). Training and Technical Resources Development Solar Turbine Titan 130 \& Thermodyne. Solar Turbine International.

Electric, G. (2003). Instruction, Operation and Maintenance Manual LM 2500. Balikpapan: Nuovo Pignone.

Gaesang, D., \& Aditia. (2018). Engine Replacement Report. Mechanic. Balikpapan: PT. Pertamina Hulu Mahakam.

Giampaolo, A. (2006). Gas Turbine Handbook Pronciple and Practice Third Edition. Lilburn:

The Fairmont Press. 


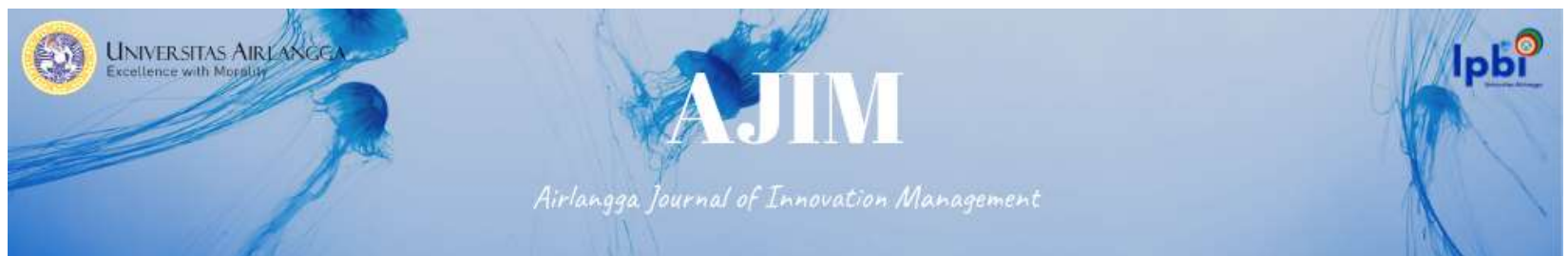

INDONESIE, T. E. (2007). Tunu Field Development Project Phase 11 N / EPSC 11+12.

Balikpapan: TOTAL E\&P INDONESIE.

Kalimattullah, A. N. (2019). Performansi Kompressor dengan Flowrate Gas Minimum pada Lapangan Tunu North - NPU PT. Pertamina Hulu Mahakam. Balikpapan: Universitas Balikpapan.

Mahmuddin. (2017). Studi Eksperimental Penurunan Tekanan Aliran Melewati Belokan Pipa Horizontal dengan Variasi Rasio R/D. Teknologi, 18, 45 - 52.

Mechanic Team. (2004). Gas Turbine GE LM 2500. Balikpapan: Total E\&P Indonesie.

Oyedepo, S. (2014). Thermodynamic Analysis of a Gas Turbine Power Plant Modeled with Evaporative Cooler. International Journal of Thermodynamics (IJoT), 17(1), 14-20. doi:10.5541/ijot.480

Pathirathna, K. (2013). Gas Turbine Thermodynamic and Performance Analysis Methods Using Available Catalog Data. Gavle: University of Gavle.

Pignone, N. (2001). Instruction, Operation and Maintenance Manual Gas Turbine LM 2500. Florence: Nuovo Pignone.

Ramadhan, T. A. (2018). Efisiensi Turbin Gas sebelum dan sesudah overhaul combustion inspection di GTG Utility I PT. Petrokimia Gresik. Yogyakarta: Universitas Gadjah Mada.

Stoecker, W. F. (1989). Design of Thermal Systems third edition. Singapore: McGraw-Hili Book Co.

Team, M. (2009). 8000 hr preventive maintenance general electric turbine engine compressor. Balikpapan: TOTAL E\&P INDONESIE.

TOTAL. (2002). Turbines. Balikpapan: Total E\&P Indonesie.

Total Finaelf. (2002). Tunu Field Development Project Phase 8. Balikpapan: Total Finaelf E\&P Indonesie.

Wahzudi, T., Ariestyanti, A. P., \& Pramaeda, T. D. (2017). Makalah Metode Newton-Raphson. Yogyakarta: Universitas PGRI Yogyakarta. 